\title{
Naxis
}

\section{Tabu i wstyd w literaturze i kulturze}

Franz Kafka napisał w Procesie:

Gasnącymi oczyma widział jeszcze K., jak panowie, blisko przed jego twarzą, policzek przy policzku, śledzili ostateczne rozstrzygnięcie. "Jak pies!”- powiedział do siebie: było tak, jak gdyby wstyd miał go przeżyć1.

To znane wszystkim czytelnikom i przez wszystkich bodaj zapamiętane zakończenie genialnej powieści wyznacza w jakiś sposób horyzont nowoczesnej refleksji o wstydzie jako odczuciu przekraczającym naszą indywidualną tożsamość, świadomość czy intuicję ciała, a być może również to, co możliwe do wyrażania w logosie międzyludzkiej komunikacji. Odczucie to łączy się z momentami granicznymi ludzkiej biografii: narodzinami i śmiercią oraz wielorako powiązaną z nimi seksualnością. Jego związek z genezą fundamentów kultury potwierdza biblijna przypowieść o zerwaniu owocu z Drzewa Wiadomości Dobrego i Złego, której interpretację humaniści i egzegeci nieustannie ponawiają, tak, jakby jej sens pozostawał niezgłębiony.

Projektując bieżący numer rocznika „Napis” uznaliśmy za zasadne włączenie w nurt tej refleksji (filozoficznej, antropologicznej, etnologicznej, psychologicznej) nad tekstami literackimi oraz użytkowymi (a raczej należących do zdefiniowanej przez Profesora Janusza Maciejewskiego klasy „obszarów trzecich” literatury) od renesansu aż po współczesność. Warto bowiem, naszym zdaniem, „osaczać” tajemnicę tego, co niewyrażalne, a zarazem konstytutywne dla ludzkiej tożsamości i kultury, postrzegając wcielenia i odgałęzienia topiki tabu i wstydu przez pryzmat literackiej różnorodności. Zdecydowaliśmy się na to tym skwapliwiej, że teksty z poprzedniej serii naszego pisma (seria XVII pod hasłem Jawne i ukryte $w$ literaturze i kulturze) przygotowują czytelników do rozpoznania tego problemu, którego seria zatytułowana Tabu i wstyd stanowi zarówno rozwinięcie, jak i bardziej sprecyzowaną kontynuację.

1 F. Kafka, Proces, tłum. B. Schulz, Wrocław 1997, s. 94. 
Wydaje się, że o istnieniu związku między wstydem (zjawiskiem ogólnoludzkim, powszechnym, wszystkim znanym z doświadczeń intymnej, prywatnej biografii) a antropologiczną kategorią „tabu” nie trzeba nikogo przekonywać. Warto jednak może przytoczyć słowa Sigmunda Freuda, który w swojej klasycznej książce na ten temat (Totem i tabu) pisał:

Dla nas słowo «tabu» ma dwa przeciwstawne znaczenia. $Z$ jednej strony oznacza coś świętego, poświęconego, z drugiej zaś - coś niesamowitego, niebezpiecznego, zakazanego i nieczystego. [...] Ograniczenia tabu różnią się od zakazów religijnych czy moralnych. Nie da się ich sprowadzić do przykazań boskich, albowiem $\mathrm{w}$ istocie są one zakazami same przez się; różnią się od zakazów moralnych tym, że nie da się ich włączyć w jakiś system [...]. Zakazom tabu brak wszelkiego usprawiedliwienia, geneza ich nie jest znana. [...] Przyjmuje się powszechnie, że tabu jest starsze od bogów i wywodzi się z epoki przedreligijnej².

Można zatem dojść do wniosku, że tym, co łączy tabu i wstyd (oprócz oczywistego związku przyczynowego czy też metonimicznego, polegającego na tym, że łamiąc tabu odczuwamy wstyd, nawet jeśli złamanie to nie łączy się z sankcją kary) jest wspólny im obu, niewyrażalny charakter, ich wywodzenie się ze sfery, w której logos graniczy i przeplata się z chaosem. Warto zwrócić uwagę na fakt, że jakkolwiek - w życiu codziennym - jesteśmy na ogół w stanie zidentyfikować przyczynę ogarniającego nas wstydu (np. w postaci jakiegoś zachowania, wykraczającego przeciw obyczajowej normie), to sama natura wstydu pozostaje dla nas zakryta, podobnie jak w przypadku tabu. Wyraża się to choćby w postaci bezwiednych, fizjologicznych symptomów wstydu (zaczerwienienie policzków, pocenie się, czasem przebiegające po ciele dreszcze), nad którymi nie potrafimy w żaden sposób zapanować, nawet poprzez zupełnie przekonujące rozumowanie o postaci: „przecież nie mam się czego wstydzić, to zwyczajna, ludzka rzecz”. Zarówno tabu, jak i wstyd pozostają poza naszą kontrolą, łączą się ze swoistym „wywłaszczeniem” ciała spod rządów świadomości, z niesamowitym przeczuciem „władzy Innego” nad naszą tożsamością.

Oba te zjawiska, zarazem społeczne, jak i indywidualne, oznaczają konfrontację z arché kultury i ludzkiej psychiki, w której kształtowały się kluczowe dla nich rozstrzygnięcia. Spośród często przywoływanych w tym kontekście („źródeł” czy „podstaw” kultury) maksym „ciemnego” Heraklita z Efezu, filozofa, który raczej „daje znak”, niż „mówi” lub „ukrywa”, można by przytoczyć jedną, stanowiącą odzwierciedlenie owe-

2 S. Freud, Totem i tabu, thum. J. Prokopiuk i M. Poręba, oprac. R. Reszke, Warszawa 1993, s. 23. 
go niesamowitego poczucia wywłaszczenia: „Męką jest trudzić się dla tych samych i być rządzonym”. W przytoczonym przez Kazimierza Mrówkę (jako komentarz do powyższej maksymy) wstępie do Ennead Plotyna, napisanym przez Porfiriusza, czytamy: „Plotyn, filozof naszych czasów, czuł jakby wstyd, że jest w ciele”3. Właśnie w tak fundamentalnym obszarze, związanym z cielesnością i jej strukturą, z fizjologią i przemianą materii, lecz także w kontekście historycznym: przemian obyczajów, systemów wartości, czy też norm ludzkiego zachowania (bo przecież, jak pisał ten sam Heraklit, „pory roku [...] wszystko przynoszą”4) rozwijać można humanistyczną refleksję nad tabu i wstydem, której konkretne przykłady odnajdą Czytelnicy w niniejszej serii "Napisu”.

Tom zawiera artykuły naukowe, których zakres chronologiczny sięga od piśmiennictwa epok dawnych (renesans, barok, Oświecenie, pozytywizm, Młoda Polska) poprzez Dwudziestolecie do postmodernizmu. Omówiono tu zagadnienia wiążące się z funkcjonowaniem i pojmowaniem tabu, zakresem różnych zjawisk i spraw życia zbiorowego oraz indywidualnego, poddawanych przez wieki tabuizacji. Ukazano niektóre jej źródła, konsekwencje i mechanizmy. Uwzględniono również rozumienie pojęcia „wstyd” (już w epoce staropolskiej kojarzonego ze wstrętem) oraz emocji wstydu i odczuć pokrewnych (zawstydzenia, wstydliwości itp.), poddano analizie kulturowe formy wstydu (przez-odniesienie do bezwstydu). Zagadnienia te widziane są przez pryzmat utworów poetyckich znanych twórców (Jana Kochanowskiego, Bolesława Leśmiana), powieści (klasycznych i popularnych; XIX- i XX-wiecznych; polskich i obcych; realistyczno-obyczajowych, utopijnej powieści fantastycznonaukowej i powieści graficznej); opowiadania mazurskiego (Marcina Gerssa); prozy wspomnieniowej; prozy publicystycznej (Kronik Bolesława Prusa); epistolografii (np. miłosnej barokowej przed- i poślubnej czy listów do żony Stanisława Ignacego Witkiewicza); dokumentów (np. cenzorskich raportów z czasów PRL-u, opiniujących książki), utworów trzeciego obiegu (np. obscenicznych wierszy erotycznych), z których spora część jest bezimienna lub o niepewnych atrybucjach autorskich.

Rola różnorodnych zakazów narzucanych przez instytucje zewnętrzne, a respektowanych przez ogół społeczeństwa i uwewnętrznianych przez jego członków była i jest w dalszym ciągu duża. Lektura rozpraw zawartych w tomie uświadamia bogactwo i różnorodność materiału literackiego, odsłaniającego tabuizację wielu sfer życia i kultury, materiału zaczerpniętego z m. in. z utworów literatury wysokoartystycznej; popularnej - stroniącej od głębszej refleksyjności, lecz odzwierciedlającej najwierniej panujący obyczaj; ulotnej - rozwijającej się masowo poza drukiem, na fali libertynizmu i zafascynowania witalnością seksualną; z tekstów publicystycznych i użytkowych -

3 K. Mrówka, Heraklit. Fragmenty: nowy przekład i komentarz, Warszawa 2004, s. 235.

4 Ibidem, s. 277. 
niekiedy odbijających popularny adres utworów, innym razem reprezentujących dużą klasę estetyczno-literacką.

Analizowane są tu przejawy tabu historyczno-politycznego oraz wyznaniowo-religijnego, najczęściej zaś tabu społeczno-obyczajowego, dotyczącego wstydliwej cielesności (obiecującej zakazaną, upragnioną rozkosz lub trywialnej i przerażającej jako zaprzeczenie duchowej strony życia); seksualności i erotyzmu; zawierania i zrywania związków narzeczeńskich; życia małżeńskiego; wizerunku mężczyzny i kobiety (zarówno w perspektywie patriarchalnej jak i feministycznej); relacji damsko-męskich utrzymywanych poza związkami formalnymi itp.).

Pochodną tych zakazów naczelnych, obowiązujących w danym czasie historycznym, społeczeństwie czy środowisku, jest w dużej mierze tabu językowo-tematyczne, mające duży wpływ na kształt formalny i świat przedstawiony wielu tekstów, należących do szeroko rozumianej literatury. Jest ono ukazywane nie tylko od strony ich twórców (respektujących te zakazy lub świadomie je przekraczających czy wręcz manifestacyjnie łamiących), lecz również od strony cenzury obyczajowej czy politycznej, decydującej o dopuszczeniu utworów literackich do druku - w Polsce, zarówno pod zaborami, jak i w czasach PRL-u. Respektowanie naczelnych zakazów łączone jest ze znaną zwłaszcza w czasach pozytywizmu problematyką „języka ezopowego”, ogólnie: aluzyjnością, niedomówieniem - śladami wymazywania przez pisarzy spraw uznawanych za niepożądane, niewłaściwe czy nieprzyzwoite, wreszcie milczeniem o nich. Manifestacyjne łamanie zakazów to $\mathrm{m}$. in. epatowanie wulgaryzmami i scenami erotycznymi, brutalnymi odwołaniami do cielesności, naturalistycznymi opisami aktów seksualnych, natomiast strategie podejmowane dla przekroczenia tabu ogniskują się wokół dowcipnych ujęć tego, co traktowane było jako wstydliwe, a co nagle, dzięki zastosowaniu przez autorów wyrazistej metaforyki oraz pomysłowych zabiegów językowych okazywało się zabawne i przyjemne w odbiorze.

W omówieniach głównego problemu autorzy niektórych artykułów wskazują pola semantyczne kluczowych dla tej serii naszego pisma pojęć w różnych epokach i tekstach, analizują równiė̇ wzajemne relacje między tymi pojęciami, a także pomiędzy nimi i cenzurą. Trudno tu o jednoznaczne definicje, ponieważ analityczne egzemplifikacje obejmują szeroką przestrzeń czasową, obszerny zakres zjawisk i spraw oraz rodzajów i gatunków literackich poddanych oglądowi, raz po raz dopełniając dotychczasowe pojmowanie „tabu” i „wstydu” nowymi szczegółami, nakazując relatywizację tych pojęć.

Oddając do rąk Czytelników XVIII tom „Napisu” chcemy, jak zwykle, umożliwić odbiorcom indywidualne ustosunkowanie się do zagadnień sygnowanych tytułem kolejnej monograficznej serii pisma Tabu i wstyd. Pragniemy, aby szkicowo nakreślony we wstępie rozległy teren podjętych w artykułach rozważań, zainspirowanych tematem wskazanym przez Zespół Redakcyjny naszego pisma, zachęcił Czytelników do lektury. Mamy nadzieję, że ta seria naszego pisma przyniesie korzyść humanistyce polskiej, do- 
starczy Czytelnikom satysfakcji intelektualnej, a z uwagi na dołączone prace studentów warszawskiej Akademii Sztuk Pięknych - również estetycznej.

Wydaje się, że zgromadzone w prezentowanym tomie „Napisu” prace naukowe, oprócz egzemplifikacji wymienionych powyżej uwikłań pojęć „tabu” i „wstydu” w kulturze literackiej, dowodzą jeszcze jednego - oba te zjawiska, mimo ich subiektywnego doświadczania przez jednostkę w prywatnej, a nawet intymnej sferze życia, mają także, nie mniej istotny, wymiar społeczny. Łączą się one (tak, jak przekaz literacki) z jakimś, nie zawsze określonym, „odbiorcą” naszych zachowań. Tabu odczuwamy bowiem jako zakaz par excellence zbiorowy czy też wspólnotowy, zaś wstyd przychodzi do nas - jak powiedziano wcześniej - pod postacią poczucia wywłaszczenia ciała przez nieokreśloną „Inność”, zewnętrzną wobec podmiotu. Także i ten wymiar omawianych zjawisk odnajdziemy w Procesie Kafki, w bardzo ważnej dla tej powieści, końcowej scenie; autor, pozornie beznamiętnie relacjonując ostatnie doświadczenia głównego bohatera, Józefa K., napisał tam:

Jego wzrok padł na najwyższe piętro graniczącego z kamieniołomem domu. Jak błyska światło, tak rozwarły się tam skrzydła jakiegoś okna: jakiś człowiek, słaby i nikły w tym oddaleniu i na tej wysokości, wychylił się jednym rzutem daleko przez okno i wyciągnął jeszcze dalej ramiona. Kto to był? Przyjaciel? Dobry człowiek? Ktoś, kto współczuł? Ktoś, kto chciał pomóc? Byłże to ktoś jeden? Czy byli to wszyscy?5

Z taką właśnie, tajemniczą nieokreślonością naszej egzystencji konfrontuje nas tabu i jego nieodłączny towarzysz - wstyd. Mamy nadzieję, że artykuły zgromadzone w niniejszym tomie stanowią przykład owocnych badawczych peregrynacji po tym zagadkowym, lecz nader ważnym dla wszystkich ludzi obszarze.

Barbara Wolska i Marek Pąciński

5 F. Kafka, op. cit., s. 93. 